\title{
Antiplasmodial Activity of the Low Molecular Weight Compounds from Streptomyces sp. GMR22
}

\section{Tarsa Ruli Tambunan1, Jaka Widada2 ${ }^{*}$, Ema Damayanti1,3, Tutik Dwi Wahyuningsih", Mustofa5}

1. Study Program for Biotechnology, Graduate School, Universitas Gadjah Mada, Barek, Yogyakarta 55281, Indonesia

2. Department of Agricultural Microbiology, Faculty of Agriculture, Universitas Gadjah Mada, Bulaksumur, Yogyakarta 55281, Indonesia

3. Research Division for Natural Product Technology, Indonesian Institute of Sciences, Jl. Jogja - Wonosari Gunungkidul, Yogyakarta 55861, Indonesia

4. Department of Chemistry, Universitas Gadjah Mada, Sekip Utara PO Box: BLS21, Yogyakarta 55281, Indonesia

5. Department of Pharmacology and Therapy, Faculty of Medicine, Public Health, and Nursing, Universitas Gadjah Mada, Sekip Utara, Yogyakarta 55281, Indonesia

\begin{tabular}{|c|c|}
\hline Info Article & ABSTRACT \\
\hline Submitted: $26-08-2020$ & Low molecular weight (LMW) antiplasmodial compounds isolated \\
\hline Revised: $22-10-2020$ & from bacteria, particularly Streptomyces have not been widely reported. This \\
\hline Accepted: $13-12-2020$ & study aimed to identify LMW compounds from Streptomyces sp. GMR22 as \\
\hline $\begin{array}{l}\text { *Corresponding author } \\
\text { Jaka Widada }\end{array}$ & $\begin{array}{l}\text { antiplasmodial. Isolation of the LMW compounds from the supernatant of } \\
\text { fermentation culture using solvent of } n \text {-hexane:ethylacetate (EtOAc) } \\
(85: 15 \mathrm{v} / \mathrm{v}) \text { and identified using gas chromatography-mass spectrometry (GC- }\end{array}$ \\
\hline \multirow{13}{*}{$\begin{array}{l}\text { Email: } \\
\text { jwidada@ugm.ac.id }\end{array}$} & MS). Antiplasmodial assay of $n$-hexane:EtOAc extract was carried out in vitro \\
\hline & against $P$. falciparum (3D7). Parasitemia percentage obtained through \\
\hline & microscopic observations and $50 \%$ inhibitory concentration $\left(\mathrm{IC}_{50}\right)$ obtained \\
\hline & $\begin{array}{l}\text { through probit analysis. The contirmatory antiplasmodial test was done by } \\
\text { flow cytometry using SYBR Green I for Plasmodium DNA and anti-human }\end{array}$ \\
\hline & CD235a for erythrocyte. The LMW compounds were investigated using \\
\hline & $\begin{array}{l}\text { SwissADME for drug-likeness. } n \text {-Hexane:EtOAc extract contained } 21 \text { LMW } \\
\text { compounds from alcohol, hydrocarbon, ester, aromatic/diester, diester, fatty }\end{array}$ \\
\hline & acid, and triester classes, which possessed moderate antiplasmodial activity \\
\hline & with an $\mathrm{IC}_{50}$ value of $38.61 \pm 19.06 \mu \mathrm{g} / \mathrm{mL}$. Confirmation by flow cytometry \\
\hline & $\begin{array}{l}\text { analysis showed that the extract at } 50 \mu \mathrm{g} / \mathrm{mL} \text { exhibited antiplasmodial } \\
\text { activity based on a decreased Plasmodium DNA intensity as compared to the }\end{array}$ \\
\hline & $\begin{array}{l}\text { control group. The result of drug-likeness screening obtained that } 3 \text { LMW } \\
\text { compounds were drug-likeness, namely phenylethyl alcohol, ethyl citrate, }\end{array}$ \\
\hline & and di-n-butyl phthalate. Streptomyces sp. GMR22 produced LMW \\
\hline & $\begin{array}{l}\text { compounds as antiplasmodial, and further study was needed to reinvestigate } \\
\text { and to identify antiplasmodial active compounds. }\end{array}$ \\
\hline & $\begin{array}{l}\text { Keywords: Low molecular weight compounds, Streptomyces, antiplasmodial, } \\
\text { antimalaria }\end{array}$ \\
\hline
\end{tabular}

\section{INTRODUCTION}

Molecular weight compound is one of the considerations for the successful discovery of drug compound candidates. This consideration emerged after High Throughput Screening (HTS) era, where many compounds have high molecular weights. The higher molecular weights cause compounds tend to be lead-like rather than drug-like. According to the Rule of 5 (Ro5), drug-like compounds have low molecular weights of less than $500 \mathrm{~g} / \mathrm{mol}$. Low molecular weight is one of the keys of drug-likeness for the discovery of oral bioavailability candidates (Lipinski, 2004).

Low molecular weight (LMW) compound is one of the products of secondary metabolites produced by microbes, particularly soil-dwelling bacteria (Tyc et al., 2017). Streptomyces, the soildwelling bacteria, are a well-known source for the 
production of secondary metabolites, including LMW compounds. The LMW compounds of less than $500 \mathrm{~g} / \mathrm{mol}$ or $500 \mathrm{Da}$ are commonly volatile (Schmidt et al., 2015), and known to possess biological activities (de Lima Procópio et al., 2012; Wu et al., 2015; Xing et al., 2018).

Streptomyces sp. GMR22 is one of the soildwelling bacteria isolated from Cajuput rhizospheric soil at Wanagama I Forest, Yogyakarta, Indonesia (Nurjasmi et al., 2009). This microbe is known to produce LMW compounds which possessed biological activity (Sukmawati et al., 2018), and predicted to encode biosynthetic pathways of terpenes (Herdini et al., 2017). The LMW compounds could be extracted and isolated using an organic solvent mixture. One of the LMW compounds was known as terpene (Jiang et al., 2016).

Previous studies revealed that monoterpenes and sesquiterpenes isolated from essential oils exhibited antiplasmodial activity in vitro against the $\mathrm{W} 2$ and $\mathrm{K} 1$ strain of $P$. falciparum (Boyom et al., 2011; Durant et al., 2014; Mota et al., 2012). Moreover, triterpenes also exhibited in vitro antiplasmodial activity (Isaka et al., 2010). The antiplasmodial compounds isolated from bacteria, particularly Streptomyces have not been widely reported. Therefore, Streptomyces sp. GMR22 is considered to produce LMW compounds, including terpenes as antiplasmodial.

\section{MATERIAL AND METHODS Streptomyces sp. GMR22 isolate}

Streptomyces sp. GMR22 was isolated from Cajuput rhizospheric soil at Wanagama I Forest, Yogyakarta, Indonesia, as obtained from the previous study (Nurjasmi et al., 2009). GMR22 isolate has been deposited at Indonesian Culture Collection (InaCC A148), Research Center for Biology, Indonesian Institute of Sciences, and NITE Biological Research Center (NBRC), Japan (NBRC 110112). GMR22 16S RNA sequence has been submitted in the National Center for Biotechnology Information (NCBI), accession code MN922646.

\section{Fermentation, extraction, and isolation of LMW compounds}

GMR22 isolate was inoculated on International Streptomyces Project-2 (ISP-2) medium (Alimuddin et al., 2010). The spore culture was inoculated into $50 \mathrm{~mL}$ tryptic soy broth (TSB) and incubated at $28^{\circ} \mathrm{C}$ for 3 days on a rotary shaker (150 rpm) as seed culture. Then, it was inoculated into $450 \mathrm{~mL}$ starch nitrate broth (SNB) for metabolites production (soluble starch $20.0 \mathrm{~g}, \mathrm{NaCl}$ $0.5 \mathrm{~g}, \mathrm{KNO}_{3} 1.0 \mathrm{~g}, \mathrm{~K}_{2} \mathrm{HPO}_{4} .3 \mathrm{H}_{2} \mathrm{O} 0.5 \mathrm{~g}, \mathrm{MgSO}_{4} .7 \mathrm{H}_{2} \mathrm{O}$ $0.5 \mathrm{~g}, \mathrm{FeSO}_{4} .7 \mathrm{H}_{2} \mathrm{O} 0.01 \mathrm{~g}$, per liter) and incubated at $28^{\circ} \mathrm{C}$ for 11 days on a rotary shaker $(150 \mathrm{rpm})$. The supernatant was collected by centrifugation at $5000 \mathrm{rpm}$ for 10 minutes then filtered by Whatman No.1 filtrate paper. The extraction method was carried out using an organic solvent of $n$ hexane:EtOAc $(85: 15 \mathrm{v} / \mathrm{v})$ mixture, according to Jiang et al. (2016) obtained a solid brown extract.

\section{Identification of LMW compounds and drug- likeness screening}

$n$-Hexane:EtOAc extract was dissolved in $200 \mu \mathrm{L} n$-hexane then analyzed using GC-MS (Jiang et al., 2016). In this study, GC-MS (Shimadzu QP2010S) used RTX-5 capillary column $(30 \mathrm{~m} \mathrm{x}$ $0.25 \mathrm{~mm} \times 0.25 \mu \mathrm{m})$, positive ionization $70 \mathrm{eV}$ mode, carrier gas $=$ Helium at $0.5 \mathrm{~mL} \mathrm{~min}^{-1}$ flow rate, column pressure $=13.7 \mathrm{kPa}$, linear velocity $=25.9$ $\mathrm{cm} \mathrm{sec}{ }^{-1}$, total flow $=28.0 \mathrm{~mL} \mathrm{~min} \mathrm{~m}^{-1}$, injector temperature $=300^{\circ} \mathrm{C}$ splitless mode. Oven temperature started at $70{ }^{\circ} \mathrm{C}$ (for 8 minutes), then raised $5{ }^{\circ} \mathrm{C} \mathrm{min}-1$ to $300{ }^{\circ} \mathrm{C}$ (for 26 minutes). Mass spectra were used in scan mode ranging from 28$600 \mathrm{~m} / \mathrm{z}$. The resulted mass spectra were analyzed by comparing with commercial mass spectra (NIST12, NIST62, WILEY229). The identified compounds were investigated for drug-likeness using the SwissADME web tool, which was accessed through https://www.swissadme.ch (Daina et al., 2017).

\section{Plasmodium culture and in vitro antiplasmodial assay}

The 3D7 strain of $P$. falciparum was obtained from the Eijkman Institute, Jakarta, Indonesia. In vitro antiplasmodial assay was carried out using donor blood type $\mathrm{O}^{+}$. The Plasmodium was cultured in vitro continuously, according to Trager and Jenson (1978), incubated in an incubator at $37^{\circ} \mathrm{C}$ with $5 \% \mathrm{CO}_{2}$. The trophozoite-phase of Plasmodium was synchronized by the addition of 5\% D-sorbitol every $48 \mathrm{~h}$, as reported by Lambros and Vanderberg (1979) and Mustofa et al. (2007).

One milligram $n$-hexane:EtOAc extract was dissolved in $10 \mu \mathrm{L}$ DMSO stock solution $(100,000 \mu \mathrm{g} / \mathrm{mL})$. The extract was diluted using RPMI medium to obtain final tested concentration of $0.78,6.25,25,50,100,200 \mu \mathrm{g} / \mathrm{mL}$. One hundred microlitre RPMI medium (negative control) and tested concentration of extract, respectively, were plated in 96-well microplate and followed by the addition of $100 \mu \mathrm{L}$ Plasmodium culture 
(trophozoite-phase at $0.5-1 \%$ parasitemia, $1 \%$ hematocrit) resulting from the synchronization. The antiplasmodial assay was carried out with triplicate, incubated for $72 \mathrm{~h}$ in an incubator at $37^{\circ} \mathrm{C}$ with $5 \% \mathrm{CO}_{2}$. Parasitemia was observed by making thin blood films stained by $10 \%$ Giemsa stain. Microscopic observation of the parasitemia was done using light microscopy (Nikon) at 1000x magnification in 1000 observed erythrocytes. The percentage of Plasmodium growth inhibition was obtained by counting the parasitemia on the control group multiplied by $100 \%$ (Jenett-Siems et al., 1999).

\section{Confirmatory antiplasmodial test by flow cytometry}

Confirmatory antiplasmodial test of $n$-hexane:EtOAc extract was analyzed using flow cytometry. Plasmodium DNA was stained using SYBR Green I (Invitrogen, USA) (Dery et al., 2015), and CD235a (anti-human, eBioscience, USA) as a marker for erythrocyte. The confirmatory test was carried out independently in the same culture manner as the previous antiplasmodial assay. The final concentration of the tested extract was $50 \mu \mathrm{g} / \mathrm{mL}$, and DMSO $(0.1 \% \mathrm{v} / \mathrm{v})$ as the extracting solvent was used as a control group. The test was performed in duplicate with Plasmodium uninfected-erythrocyte was used as a comparison.

Two hundred microlitre of each treatment was centrifuged at $7000 \mathrm{rpm}$ for $10 \mathrm{~min}$. Then, each of $50 \mu \mathrm{L}$ erythrocyte pellet was transferred into a microtube. Afterward, $2 \mu \mathrm{L}$ of CD235a and $2 \mu \mathrm{L}$ of SYBR Green I (1000x final concentration) were added consecutively then it was incubated in the dark at room temperature for $30 \mathrm{~min}$. The pellet was washed once by adding $1 \mathrm{~mL}$ of PBS and centrifuged at 2000rpm for $5 \mathrm{~min}$. Pellet was then collected and dissolved in $400 \mu \mathrm{L}$ flow cytometry buffer for subsequent analysis using a flow cytometer (BD FACSCanto ${ }^{\mathrm{TM}}$ II).

\section{Ethical clearance}

In vitro antiplasmodial assay used donor blood from an adult male with blood type $\mathrm{O}^{+}$, and approved by the Medical and Health Research Ethics Committee (MHREC) of Faculty of Medicine, Public Health, and Nursing, Universitas Gadjah Mada, Yogyakarta, Indonesia (KE/FK/0869/EC/2019). The ethics committee was recognized by The Forum for Ethical Review Committees in Asia and the Western Pacific (FERCAP).

\section{Statistical analysis}

The result of in vitro antiplasmodial assay was presented as mean \pm standard error of the mean (SEM) of parasitemia percentage and growth inhibition percentage. One-way ANOVA followed by the LSD post hoc statistical test was done using SPSS 24 software (IBM Corp., USA). The antiplasmodial activity was defined by $50 \%$ inhibitory concentration ( $\mathrm{IC}_{50}$ ) obtained through probit analysis (95\% confidence interval) using SPSS 24 software (IBM Corp., USA).

\section{RESULTS AND DISCUSSION Identification of LMW compounds and drug- likeness screening}

The detected compounds profile from $n$-hexane:EtOAc extract after analysed using GC-MS is presented on the chromatogram (Figure 1). Twenty one compounds were identified as alcohol, hydrocarbon, ester, aromatic/diester, diester, fatty acid, and triester classes, which have molecular weights of less than $500 \mathrm{~g} / \mathrm{mol}$ (Figure 1). Meanwhile, 4 silicates have molecular weights of more than $500 \mathrm{~g} / \mathrm{mol}$ (Table I). The result of druglikeness screening using SwissADME based on the Ro5 showed that 3 compounds were drug-likeness, 16 compounds were non-drug-likeness, and 2 compounds could not be predicted. The classified drug-likeness compounds are phenylethyl alcohol, ethyl citrate, and di-n-butyl phthalate (DBP).

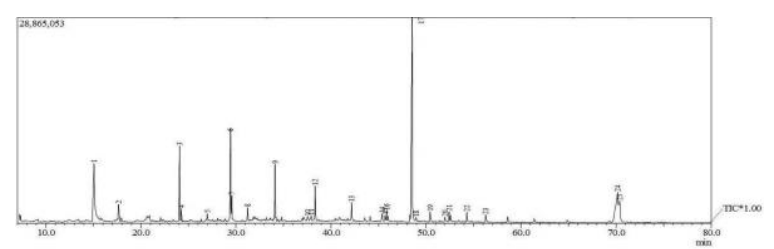

Figure 1. GC-MS chromatogram of $n$-hexane:EtOAc extract

The main component in the extract was di-noctyl phthalate (DOP), an aromatic/diester class that had the highest area proportion (30.77\%). Other main components were phenylethyl alcohol (13.06\%) and 2-butyl-1-hexadecanol (11.41\%) from alcohol class, followed by 1-tetradecene $(7.87 \%)$, tridecane $(6.05 \%)$, and (E)-3-octadecene (5.21\%) from hydrocarbon class. Meanwhile, other compounds were below $5 \%$. Additionally, this study found that the extract contained silicate anion tetramer, which is commonly nanoparticle composite. 
Table I. Identification of the LMW compounds from $n$-hexane:EtOAc extract and drug-likeness screening for potential compound candidates.

\begin{tabular}{|c|c|c|c|c|c|c|c|c|c|c|c|}
\hline \multirow{2}{*}{ Peak } & \multirow{2}{*}{$\begin{array}{c}\text { RT } \\
(\mathrm{min})^{\mathrm{a}}\end{array}$} & \multirow{2}{*}{ Compound } & \multirow{2}{*}{$\begin{array}{c}\text { MW } \\
(\mathrm{g} / \mathrm{mol})^{\mathrm{b}}\end{array}$} & \multirow{2}{*}{$\begin{array}{c}\text { Area } \\
(\%)\end{array}$} & \multirow{2}{*}{ Class $^{c}$} & \multicolumn{6}{|c|}{ Drug-likeness (Ro5) $^{d}$} \\
\hline & & & & & & Lipophilicity & Size & TPSA & Solubility & Saturation & Flexibility \\
\hline 1 & 15.076 & $\begin{array}{l}\text { Phenylethyl } \\
\text { alcohol }\end{array}$ & 122 & 13.06 & Alcohol & $\mathrm{v}$ & $\mathrm{v}$ & $\mathrm{v}$ & $\mathrm{v}$ & $\mathrm{v}$ & $\mathrm{v}$ \\
\hline 2 & 17.668 & 1-Dodecene & 168 & 1.99 & Hydrocarbon & $\mathrm{x}$ & $\mathrm{v}$ & $\mathrm{v}$ & $\mathrm{v}$ & $\mathrm{v}$ & $\mathrm{v}$ \\
\hline 3 & 24.084 & 1-Tridecene & 182 & 6.05 & Hydrocarbon & $\mathrm{x}$ & $\mathrm{v}$ & $\mathrm{v}$ & $\mathrm{v}$ & $\mathrm{v}$ & $\mathrm{v}$ \\
\hline 4 & 24.274 & Tridecane & 184 & 0.98 & Hydrocarbon & $\mathrm{x}$ & $\mathrm{v}$ & $\mathrm{v}$ & $\mathrm{v}$ & $\mathrm{v}$ & $\mathrm{v}$ \\
\hline 5 & 27.002 & $\begin{array}{l}\text { 4-Methyl- } \\
\text { undecane }\end{array}$ & 170 & 0.79 & Hydrocarbon & $\mathrm{x}$ & $\mathrm{v}$ & $\mathrm{v}$ & $\mathrm{v}$ & $\mathrm{v}$ & $\mathrm{v}$ \\
\hline 6 & 29.438 & 1-Tetradecene & 196 & 7.87 & Hydrocarbon & $\mathrm{x}$ & $\mathrm{v}$ & $\mathrm{v}$ & $\mathrm{v}$ & $\mathrm{v}$ & $\mathrm{v}$ \\
\hline 7 & 29.578 & $\begin{array}{l}\text { 4,8-Dimethyl- } \\
\text { tridecane }\end{array}$ & 212 & 1.94 & Hydrocarbon & $\mathrm{x}$ & $\mathrm{v}$ & $\mathrm{v}$ & $\mathrm{v}$ & $\mathrm{v}$ & $\mathrm{v}$ \\
\hline 8 & 31.247 & Ethyl citrate & 276 & 1.32 & Ester & $\mathrm{v}$ & $\mathrm{v}$ & $\mathrm{v}$ & $\mathrm{v}$ & $\mathrm{v}$ & $\mathrm{v}$ \\
\hline 9 & 34.123 & (E)-3-Octadecene & 252 & 5.21 & Hydrocarbon & $\mathrm{x}$ & $\mathrm{v}$ & $\mathrm{v}$ & $\mathrm{v}$ & $\mathrm{v}$ & $\mathrm{v}$ \\
\hline 10 & 37.560 & $\begin{array}{c}\text { (Z)-3-Methyl-2- } \\
\text { decene }\end{array}$ & 154 & 0.78 & Hydrocarbon & $\mathrm{x}$ & $\mathrm{v}$ & $\mathrm{v}$ & $\mathrm{v}$ & $\mathrm{v}$ & $\mathrm{v}$ \\
\hline 11 & 37.932 & $\begin{array}{l}\text { Di-n-butyl } \\
\text { phthalate }\end{array}$ & 278 & 0.94 & $\begin{array}{l}\text { Aromatic/ } \\
\text { diester }\end{array}$ & $\mathrm{v}$ & $\mathrm{v}$ & $\mathrm{v}$ & $\mathrm{v}$ & $\mathrm{v}$ & $\mathrm{v}$ \\
\hline 12 & 38.344 & 1-Nonadecene & 266 & 3.26 & Hydrocarbon & $\mathrm{x}$ & $\mathrm{v}$ & $\mathrm{v}$ & $\mathrm{v}$ & $\mathrm{v}$ & $\mathrm{v}$ \\
\hline 13 & 42.185 & (E)-3-Eicosene & 280 & 1.81 & Hydrocarbon & $\mathrm{x}$ & $\mathrm{v}$ & $\mathrm{v}$ & $\mathrm{v}$ & $\mathrm{v}$ & $\mathrm{v}$ \\
\hline 14 & 45.395 & Oleamide & 281 & 1.02 & Fatty acid & $\mathrm{x}$ & $\mathrm{v}$ & $\mathrm{v}$ & $\mathrm{v}$ & $\mathrm{v}$ & $\mathrm{v}$ \\
\hline 15 & 45.702 & 1-Dococene & 308 & 0.67 & Hydrocarbon & $\mathrm{x}$ & $\mathrm{v}$ & $\mathrm{v}$ & $\mathrm{v}$ & $\mathrm{v}$ & $\mathrm{v}$ \\
\hline 16 & 45.875 & Dioctyl-adipate & 370 & 0.84 & Diester & $\mathrm{x}$ & $\mathrm{v}$ & $\mathrm{v}$ & $\mathrm{v}$ & $\mathrm{v}$ & $\mathrm{v}$ \\
\hline 17 & 48.555 & $\begin{array}{l}\text { Di-n-octyl- } \\
\text { phthalate }\end{array}$ & 390 & 30.77 & $\begin{array}{c}\text { Aromatic/ } \\
\text { diester }\end{array}$ & $\mathrm{x}$ & $\mathrm{v}$ & $\mathrm{v}$ & $\mathrm{v}$ & $\mathrm{v}$ & $\mathrm{v}$ \\
\hline 18 & 48.961 & 1-Heptacosanol & 396 & 0.63 & Alcohol & $\mathrm{x}$ & $\mathrm{v}$ & $\mathrm{v}$ & $\mathrm{v}$ & $\mathrm{v}$ & $\mathrm{v}$ \\
\hline 19 & 50.445 & $\begin{array}{l}\text { Silicate anion } \\
\text { tetramer }\end{array}$ & 888 & 1.19 & Silicate & o & o & o & o & o & o \\
\hline 20 & 52.005 & $\begin{array}{l}\text { 2-Methyl-1- } \\
\text { hexadecanol }\end{array}$ & 256 & 0.71 & Alcohol & $\mathrm{x}$ & $\mathrm{v}$ & $\mathrm{v}$ & $\mathrm{v}$ & $\mathrm{v}$ & $\mathrm{v}$ \\
\hline 21 & 52.441 & $\begin{array}{l}\text { Silicate anion } \\
\text { tetramer }\end{array}$ & 888 & 0.81 & Silicate & o & o & o & o & o & o \\
\hline 22 & 54.307 & $\begin{array}{l}\text { Silicate anion } \\
\text { tetramer }\end{array}$ & 888 & 0.73 & Silicate & o & o & o & o & o & o \\
\hline 23 & 56.291 & $\begin{array}{l}\text { Silicate anion } \\
\text { tetramer }\end{array}$ & 888 & 0.91 & Silicate & o & o & o & o & o & o \\
\hline 24 & 70.166 & $\begin{array}{l}\text { 2-Butyl-1- } \\
\text { hexadecanol }\end{array}$ & 298 & 11.41 & Alcohol & o & o & o & o & 0 & o \\
\hline 25 & 70.372 & $\begin{array}{c}\text { Glyceryl } \\
\text { pentanoate }\end{array}$ & 344 & 4.32 & Triester & o & o & o & o & o & o \\
\hline
\end{tabular}

a: Retention time (minute); b: molecular weight; c: source: https://pubchem.ncbi.nlm.nih.gov; d: SwissADME prediction analysis based on Ro5 (Lipinski et al., 2001); v: eligible to Ro5; x: not eligible to Ro5; o: could not be predicted

It hypothesized that Streptomyces sp. GMR22 might secrete enzymes and could lead to the synthesis of silicate such as Actinobacter sp., which has been reported by Singh et al. (2008).

Extraction using an organic solvent mixture aimed to obtain the LMW compounds, including the class of terpenes. However, the terpenes were not identified. The GC-MS used in this study was RTX-5 capillary column, which was different from Jiang et al. (2016). Yamada et al. (2015) reported that 2methylisoborneol was only the trace that could be detected in liquid culture after analyzed using GC-
MS. Therefore, the terpenes level in the extract might also be trace.

This study found that the classified druglikeness compounds were phenylethyl alcohol, ethyl citrate, and DBP from alcohol, ester, and aromatic/diester classes, respectively. This elucidates that the compounds have physicochemical properties, which are associated with acceptable aqueous solubility and intestinal permeability. Therefore, the compounds are predicted to be suitable for oral bioavailability candidates (Daina et al., 2017; Lipinski, 2004). 
The previous studies revealed that phenylethyl alcohol possessed antifungal activity (Xing et al., 2018), whereas DBP was reported to possess antimicrobial activity (Roy et al., 2006). Meanwhile, ethyl citrate was the first report in this study. This finding showed that the classified druglikeness compounds were considered to have other biological activities.

One of the classified non-drug-likeness compounds was DOP, which possessed biological activities. Fitriastuti et al. (2020) reported that ethanol extract fraction of temu mangga (Curcuma mangga Val.) contained DOP, which also identified using GC-MS. They reported that DOP possessed potency as an antimalaria compound. Moreover, DOP was reported to possess antimicrobial activity (Zothanpuia et al., 2018).

\section{In vitro antiplasmodial assay}

The result of antiplasmodial assay of n-hexane:EtOAc extract (Figure 2). It showed that the parasitemia percentage was inversely correlated to the growth inhibition percentage.

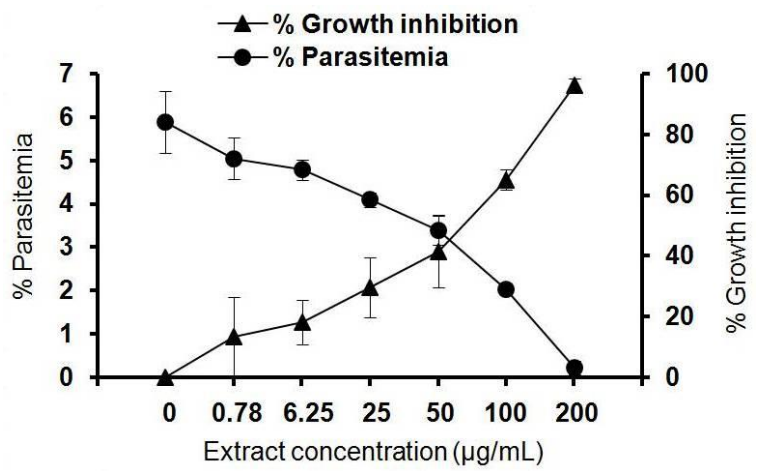

Figure 2. The correlation between parasitemia percentage and growth inhibition percentage of $P$. falciparum culture after treatment of extract concentration at $0,0.78,6.25,25,50,100$, $200 \mu \mathrm{g} / \mathrm{mL}$.

One-way ANOVA statistical test showed that the extract reduced the parasitemia percentage significantly as compared to the control group $(p<0.00)$. Likewise, the LSD post hoc test showed there was a significant difference between each extract treatment compared to the control group $(\mathrm{p}<0.05)$. The extract activity as antiplasmodial obtained an $\mathrm{IC}_{50}$ value of $38.61 \pm 19.06 \mu \mathrm{g} / \mathrm{mL}$. This shows that the extract exhibited moderate antiplasmodial activity with $\mathrm{IC}_{50}$ below $50 \mu \mathrm{g} / \mathrm{mL}$ as reported by Kaharudin et al. (2020).
The compound's content of the extract is believed to be active antiplasmodial compounds. DOP, one of the main compounds, was reported being potential as antimalaria (Fitriastuti et al., 2020). They reported that the antimalaria test was carried out by a heme polymerization inhibition method, and the result obtained an IC 50 value of $1.479 \mu \mathrm{g} / \mathrm{mL}$. Although phthalates are commonly encountered as plasticizers or pollutants from industrial wastes (Xu et al., 2020), other studies revealed that phthalate derivatives could be biologically produced by either Streptomyces (Mangamuri et al., 2016; Roy et al., 2006; Zothanpuia et al., 2018) or filamentous fungi through shikimic acid pathway (Tian et al., 2016).

In this study, the use of donor blood type $\mathrm{O}^{+}$ aimed to successfully facilitate the in vitro cultivation of Plasmodium parasites. Theron et al. (2018) reported that $P$. falciparum preferred to invade donor blood type $\mathrm{O}^{+}$rather type $\mathrm{A}^{+}, \mathrm{B}^{+}$, and $\mathrm{AB}^{+}$for an in vitro culture. Thereby, the donor blood type $\mathrm{O}^{+}$became an advantage for the in vitro cultivation of $P$. falciparum.

\section{Confirmatory antiplasmodial test by flow cytometry}

The confirmatory antiplasmodial test results and fluorescence intensity of Plasmodium DNA and detected erythrocyte are also presented (Figure 3).

Area of SYBR Green I and CD235a, which stained the Plasmodium DNA and erythrocyte, respectively (Figure 3). Q1 indicates the area of SYBR Green I negative and CD235a positive. Q2 indicates the area of $P$. falciparum infectederythrocyte and SYBR Green I positive. Q3 indicates the area of SYBR Green I negative, but CD235a positive for erythrocyte debris. Q4 indicates the area of $P$. falciparum uninfectederythrocyte and CD235a positive. The fluorescence intensity of SYBR Green I represents the DNA of Plasmodium infected-erythrocyte, and the fluorescence intensity of CD235a represents the detected erythrocyte. The \% total erythrocyte represents the detected erythrocyte count. The \% erythrocyte (uninfected) represents the $P$. falciparum uninfected-erythrocyte count, whereas the $\%$ parasitemia (infected) represents $P$. falciparum infected-erythrocyte count. The \% inhibition is the $P$. falciparum growth inhibition percentage after the treatment compared to the control. 
(a)

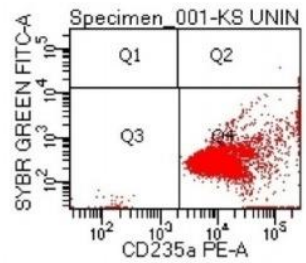

(b)

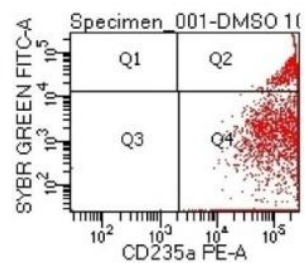

(c)

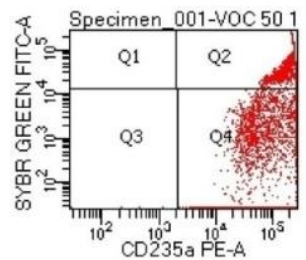

(d)

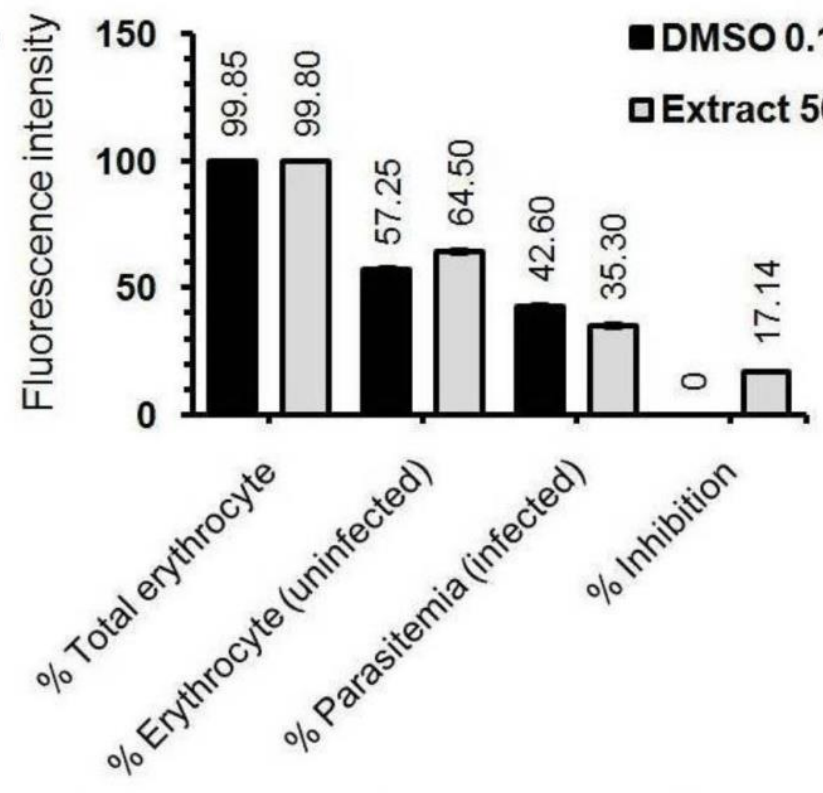

Figure 3. The flow cytometry analysis results of Plasmodium DNA and erythrocyte on the group of (a) $P$. falciparum uninfected-erythrocyte and P. falciparum culture after treatment of (b) DMSO and (c) extract 50 $\mu \mathrm{g} / \mathrm{mL}$, respectively, which showed a distinction percentage among groups based on (d) the fluorescence intensity of the detected erythrocyte (both total and uninfected), the percentage of parasitemia (the DNA of $P$. falciparum infected-erythrocyte), and the percentage of inhibition of P. falciparum growth

The detected erythrocyte intensity in both groups was equal. Thus, the total erythrocyte count was proportional. The control group showed uninfected-erythrocyte intensity lower than the treatment. This is in line with Kotepui et al. (2015). They reported that $P$. falciparum infection with high parasitemia showed a decreased total erythrocyte count as compared to P. falciparum infection with low parasitemia. The parasitemia percentage was found inversely correlated to the inhibition percentage on the flow cytometry. This is in line with the result of previous microscopic analysis. Hence, it shows that the extract exhibited potency as antiplasmodial.

\section{CONCLUSION}

Further research was needed to reinvestigate and to identify other antiplasmodial active compounds besides DOP resulted/generated from Streptomyces sp. GMR22.

\section{ACKNOWLEDGEMENTS}

This work was funded from 2019-2020 by the Indonesian Ministry of Research, Technology, and Higher Education through the Basic Research program (Number: 2787/UN1.DITLIT/DIT.LIT/LT /2019). The authors thank Miss. Mosa Rini Nurul Hidayati and Mrs. Tri Purwanti for technical assistance in an antiplasmodial assay and in the fermentation process, respectively.

\section{REFERENCES}

Alimuddin, A., Asmara, W., Widada, J., Mustofa, M., and Nurjasmi, R. (2010). An actinomycetes producing anticandida isolated from cajuput rhizosphere: partial identification of isolates and amplification of PKS-I genes. Indonesian Journal of Biotechnology, 15(1), 1-8.

Boyom, F. F., Ngouana, V., Kemgne, E. A. M., Zollo, P. H. A., Menut, C., Bessiere, J. M., Gut, J., and Rosenthal, P. J. (2011). Antiplasmodial volatile extracts from Cleistopholis patens Engler \& Diels and Uvariastrum pierreanum Engl.(Engl. \& Diels)(Annonaceae) growing in Cameroon. Parasitology research, 108(5), 1211-1217.

Daina, A., Michielin, O., and Zoete, V. (2017). SwissADME: a free web tool to evaluate 
pharmacokinetics, drug-likeness and medicinal chemistry friendliness of small molecules. Scientific reports, 7, 42717.

de Lima Procópio, R. E., da Silva, I. R., Martins, M. K., de Azevedo, J. L., and de Araújo, J. M. (2012). Antibiotics produced by Streptomyces. The Brazilian Journal of infectious diseases, 16(5), 466-471.

Dery, V., Duah, N. O., Ayanful-Torgby, R., Matrevi, S. A., Anto, F., and Quashie, N. B. (2015). An improved SYBR Green-1-based fluorescence method for the routine monitoring of Plasmodium falciparum resistance to antimalarial drugs. Malaria Journal, 14(1), 1-6.

Durant, A. A., Rodríguez, C., Herrera, L., Almanza, A., Santana, A. I., Spadadora, C., and Gupta, M. P. (2014). Anti-malarial activity and HS-SPMEGC-MS chemical profiling of Plinia cerrocampanensis leaf essential oil. Malaria Journal, 13(1), 1-9.

Fitriastuti, D., Julianto, T. S., and Iman, A. W. N. (2020). Identification and Heme Polymerization Inhibition Activity (HPIA) Assay of Ethanolic Extract and Fraction of Temu Mangga (Curcuma mangga Val.) Rhizome. EKSAKTA: Journal of Sciences and Data Analysis, 20(1), 64-72.

Herdini, C., Mubarika, S., Hariwiyanto, B., Wijayanti, N., Hosoyama, A., Yamazoe, A., Nojiri, H., and Widada, J. (2017). Secondary bioactive metabolite gene clusters identification of anticandida-producing Streptomyces sp. GMR22 isolated from Wanagama forest as revealed by genome mining approach. Indonesian Journal of Pharmacy, 28(1), 2633.

Isaka, M., Yangchum, A., Rachtawee, P., Komwijit, S., and Lutthisungneon, A. (2010). Hopane-type triterpenes and binaphthopyrones from the scale insect pathogenic fungus Aschersonia paraphysata BCC 11964. Journal of natural products, 73(4), 688-692.

Jenett-Siems, K., Mockenhaupt, F. P., Bienzle, U., Gupta, M. P., and Eich, E. (1999). In vitro antiplasmodial activity of Central American medicinal plants. Tropical Medicine \& International Health, 4(9), 611-615.

Jiang, Z., Kempinski, C., and Chappell, J. (2016). Extraction and analysis of terpenes/terpenoids. Current protocols in plant biology, 1(2), 345-358.

Kaharudin, F. A., Zohdi, R. M., Mukhtar, S. M., Sidek, H. M., Bihud, N. V., Rasol, N. E., Ahmad, F. B., and Ismail, N. H. (2020). In vitro antiplasmodial and cytotoxicity activities of crude extracts and major compounds from Goniothalamus lanceolatus. Journal of ethnopharmacology, 254, 112657.

Kotepui, M., Piwkham, D., PhunPhuech, B., Phiwklam, N., Chupeerach, C., and Duangmano, S. (2015). Effects of malaria parasite density on blood cell parameters. PLoS One, 10(3), e0121057.

Lambros, C., and Vanderberg, J. P. (1979). Synchronization of Plasmodium falciparum erythrocytic stages in culture. The Journal of parasitology, 418-420.

Lipinski, C. A. (2004). Lead-and drug-like compounds: the rule-of-five revolution. Drug Discovery Today: Technologies, 1(4), 337-341.

Lipinski, C. A., Lombardo, F., Dominy, B. W., and Feeney, P. J. (2001). Experimental and computational approaches to estimate solubility and permeability in drug discovery and development settings. Advanced Drug Delivery Reviews, 46(1-3), 326.

Mangamuri, U., Muvva, V., Poda, S., Naragani, K., Munaganti, R. K., Chitturi, B., and Yenamandra, V. (2016). Bioactive metabolites produced by Streptomyces Cheonanensis VUK-A from Coringa mangrove sediments: isolation, structure elucidation and bioactivity. 3 Biotech, 6(1), 1-8.

Mota, M. L., Lobo, L. T. C., da Costa, J. M. G., Costa, L. S., Rocha, H. A., e Silva, L. F. R., Pohlit, A. M., and de Andrade Neto, V. F. (2012). In vitro and in vivo antimalarial activity of essential oils and chemical components from three medicinal plants found in northeastern Brazil. Planta medica, 78(07), 658-664. Mustofa, Sholikhah, E., and Wahyuono, S. (2007). In vitro and in vivo antiplasmodial activity and cytotoxicity of extracts of Phyllanthus niruri L. herbs traditionally used to treat malaria in Indonesia. The Southeast Asian Journal of Tropical Medicine and Public Health, 38(4), 609-615.

Nurjasmi, R., Widada, J., and Ngadiman, N. (2009). Diversity of actinomycetes at several forest types in Wanagama I Yogyakarta and their potency as a producer of antifungal compound. Indonesian Journal of Biotechnology, 14(2), 1196-1205.

Roy, R. N., Laskar, S., and Sen, S. K. (2006). Dibutyl phthalate, the bioactive compound 
produced by Streptomyces albidoflavus 321.2. Microbiological research, 161(2), 121126.

Schmidt, R., Cordovez, V., De Boer, W., Raaijmakers, J., and Garbeva, P. (2015). Volatile affairs in microbial interactions. The ISME journal, 9(11), 2329-2335.

Singh, S., Bhatta, U. M., Satyam, P., Dhawan, A., Sastry, M., and Prasad, B. (2008). Bacterial synthesis of silicon/silica nanocomposites. Journal of Materials Chemistry, 18(22), 26012606.

Sukmawati, N., Widada, J., and Widianto, D. (2018). Potency of volatile organic compounds from Streptomyces sp. GMR22 and GMY01 in inhibiting Fusarium oxysporum f.sp. cubense (Foc). growth. Unpublished.

Theron, M., Cross, N., Cawkill, P., Bustamante, L. Y., and Rayner, J. C. (2018). An in vitro erythrocyte preference assay reveals that Plasmodium falciparum parasites prefer Type 0 over Type A erythrocytes. Scientific reports, 8(1), 1-9.

Tian, C., Ni, J., Chang, F., Liu, S., Xu, N., Sun, W., Xie, Y., Guo, Y., Ma, Y., and Yang, Z. (2016). BioSource of di-n-butyl phthalate production by filamentous fungi. Scientific reports, 6, 1-8.

Trager, W., and Jenson, J. B. (1978). Cultivation of malarial parasites. Nature, 273(5664), 621622.

Tyc, O., Song, C., Dickschat, J. S., Vos, M., and Garbeva, P. (2017). The ecological role of volatile and soluble secondary metabolites produced by soil bacteria. Trends in microbiology, 25(4), 280-292.

Wu, Y., Yuan, J., E, Y., Raza, W., Shen, Q., and Huang, Q. (2015). Effects of volatile organic compounds from Streptomyces albulus NJZJSA2 on growth of two fungal pathogens. Journal of basic microbiology, 55(9), 11041117.

Xing, M., Zheng, L., Deng, Y., Xu, D., Xi, P., Li, M., Kong, G., and Jiang, Z. (2018). Antifungal activity of natural volatile organic compounds against litchi downy blight pathogen Peronophythora litchii. Molecules, 23(2), 358.

Xu, Z., Xiong, X., Zhao, Y., Xiang, W., and Wu, C. (2020). Pollutants delivered every day: Phthalates in plastic express packaging bags and their leaching potential. Journal of hazardous materials, 384, 1-10.

Yamada, Y., Kuzuyama, T., Komatsu, M., Shin-ya, K., Omura, S., Cane, D. E., and Ikeda, H. (2015). Terpene synthases are widely distributed in bacteria. Proceedings of the National Academy of Sciences, 112(3), 857-862.

Zothanpuia, Passari, A. K., Yadav, M. K., and Singh, B. P. (2018). In vitro evaluation of antimicrobial activities and antibiotic susceptibility profiling of culturable actinobacteria from fresh water streams. Indian Journal of Experimental Biology, 56, 665-673. 